\title{
Dialectical Shades of Noir: The Case of Ignacio Padilla's Espiral de artillería
}

Este artículo analiza la tensión dialéctica del género negro tal como aparece en Espiral de artillería (2003), de Ignacio Padilla. Los mismos designios del protagonista de establecerse como sujeto acaban minándolo, transformándolo en víctima u objeto de las fuerzas que pretende controlar. En un gesto hegeliano, dicha dialéctica le permite al anti-héroe encontrar residuos de sí mismo en el mundo de afuera. Si bien tal posicionamiento implica un giro trágico en una buena parte de las obras clásicas del género negro, en el contexto del Crack mexicano, generación a la que pertenece Padilla, refleja el deseo por parte del autor de afirmar la globalidad y la llamada "literatura del mundo".

Palabras clave: Ignacio Padilla, el género negro, la dialéctica, el Crack mexicano

This article analyzes the dialectical tension of the noir genre as it appears in Ignacio Padilla's Espiral de artillería (2003). Within the noir dialectic, the protagonist's very efforts to establish himself as subject render him a prisoner of his own scheming. Such dialectic movement, according to Hegelian theory, allows the anti-hero to encounter traces of himself within the outside world. Though such an encounter typically has tragic implications in most noir works, within the context of the Mexican Crack, it reflects the author's desire to affirm globality and World Literature.

Keywords: Ignacio Padilla, Noir Literature, Dialectics, The Mexican Crack

In addition to echoing classic detective authors such as Edgar Allan Poe or Sir Arthur Conan Doyle, certain novels by the Mexican Crack generation dovetail with the noir tradition. This darker variant of crime fiction entails a distinct register of philosophical, political, and ethical concerns, depicting a world devoid of hope, justice and meaning. For example, Jorge Volpi's La paz de los sepulcros (1995) paints a nightmarish portrait of the Mexican state, one whose elected officials indulge in necrophilia during the wee hours of the night, while his more acclaimed En busca de Klingsor (1999) asserts the essential opacity of Nazi conspiracy and questions the conventions of

REVISTA CANADIENSE DE ESTUDIOS HISPÁNICOS 43.2 (INVIERNO 2OI9) 
traditional detective fiction. According to Tomás Regalado López, "Las convenciones policíacas no son más que un formalismo genérico que, además de captar la atención del lector, permiten a Volpi utilizar un sistema epistemológico de valores racionales fijos con el fin de demostrar su ineficacia en el develamiento de la verdad" ("Borges" 156). Padilla's Amphitryon (2000) also takes on the crimes of the Third Reich and muses about the possible duplicities of history itself, all the while questioning the prospect of international justice. Ignacio Sánchez Prado asserts that the novel challenges accepted notions of history, while placing its wager on literature. According to the critic, the novel affirms "a subjectivity with no space, time, or allegorical meaning that embodies the impossibility of any kind of testimonial memory. The consequence of this impossibility, as the novel's aesthetics and politics, is that literature ultimately becomes a record of what evades material transmission" (Sánchez Prado, Strategic I2I).

Beyond the general disenchantment that permeates these Crack novels, what makes noir a fruitful vehicle of critique is its use of the Hegelian dialectic. According to Fabio Vighi, in his excellent study, Critical Theory and Film: Rethinking Ideology through Film Noir, the plot-tension of many of these novels and movies is dialectical (I). As readers, we are unable to determine whether the central hero is subject or object, as he seems to occupy a liminal space in between. Initially, the tragic protagonist of film noir asserts his place in the world as an active subject with a degree of power through schemes, heists or other forms of manipulation. However, these very efforts at control often render him a prisoner. By making a bid for subjectivity, he ironically becomes his own object.

A similar dialectical logic is present in Volpi's and Padilla's various incursions into noir. In En busca de Klingsor, for example, the physicistdetective, ironically named Francis Bacon, ${ }^{\mathrm{I}}$ has possibly been played all along by an unknown puppet master, perhaps his lover Irene or his partner in the investigation, Links. At any moment, his own actions and conclusions are potentially prompted by manipulation, as he merely follows the steps laid out for him by some unnamed rival, not unlike Borges' Erik Lönnrot. In Padilla's Amphitryon, we find a similar conundrum. In this novel, names are assumed and discarded like second-hand garb. Viktor Kretzschmar, a draftrecruit for the Austro-Hungarian army originally named Thadeus Dreyer, exchanges identity documentation with another conscript to avoid certain death at the front. After the war, the new Thadeus Dreyer becomes a hero in the Nazi Party. Both Dreyer and Kretzschmar seek to control their own fates, by assuming false identities. Dreyer even trains a secret force of impostors with the goal of supplanting Nazi officials and destroying Hitler's regime from within. Their chicanery, however, inevitably goes awry, raising questions concerning their control over destiny and history. The novel suggests that their heroic deeds have merely enacted the tragedy already 
scripted by some indifferent and sadistic God. This presence of dialectics in the key thrillers of the Crack generation merits continued consideration. In this article, I turn to Espiral de artillería (2003), a lesser-read though equally compelling novel by Padilla, to find a similar use of dialectical tension. Like the tragic sleuths of film noir, the novel's first-person protagonist loses himself in a whirlwind of fiction and political deception of his own making. As I will argue, Padilla uses the noir mode to propose a dialectical view of subjectivity, one where the subject finds himself fully entangled in a strange and threatening world that he has hitherto believed to be fully external to him.

Film noir imagery often creeps up in Padilla's work. In an interview with Tomás Regalado López, Padilla comments on the appearance of Hollywood icon Humphrey Bogart in his more acclaimed novel, Amphitryon: "Amphitryon tiene un personaje policiaco que es Humphrey Bogart, que es el personaje malo, aunque hay una parodia en el resto de la novela cuando los otros personajes se comportan también como detectives. El esquema policiaco existe sobre todo en la última parte, quizá siguiendo los pasos de Antonio Muñoz Molina, pues El invierno en Lisboa, Beltenebros y Plenilunio son novelas negras" (Historia personal ${ }_{5} 58$ ). It is no coincidence that Padilla mentions Muñoz Molina as an influence, some of whose novels are themselves postmodern pastiches of Golden-Age Hollywood film. If we add to this Padilla's interest in the figure of Bogart, it would seem that his vision of the "género negro" takes the cinematic incarnation as its point of departure. Additionally, in her tribute to Ignacio Padilla in the online journal Sin Embargo, after his untimely passing in 2016, Mónica Maristain counts film noir as one of the chief influences on Espiral de artillería. She describes the novel as a distillation of Padilla's many obsessions: "obsesiones como la fobia a la autoridad, un carácter masoquista que se curaba escribiendo, la inclinación hacia mundos particularmente oscuros como la angelología y la demonología y la pasión por el cómic y el cine negro, estos últimos elementos que consideraba su real influencia literaria" (emphasis added). While cinema obviously plays a part in the Mexican novelist's postmodern admixture of styles and references, we must remember that noir is a current found in both novelistic and cinematic discourse. This said, while I will draw upon film noir criticism for my reading of Padilla's novel, it should be recognized that these theories of dialectics and anxiety are just as prominent in novels by Raymond Chandler or James Cain as they are in cinema.

In his study of film noir, Fabio Vighi identifies a Hegelian, dialectical inversion of the subject and object:

The many twists that typify classical Hollywood film noir as a rule reveal a subtle dialectical logic at work within the narrative ... this logic implies, in an exemplary 
way, that the more the subject tries to control and manipulate external events, the more he dupes himself, since he paradoxically turns into the very object of his manipulation. (I)

In other words, the protagonist's very efforts at affirming his control over a situation, usually through scheming and manipulation, ironically render him an object. At the tragic finale, he realizes he has been played the entire time by the femme fatale or other corrupt associates.

In general, by attempting to reinforce his subjectivity, the noir hero encounters this alternate dimension of his existence where he is positioned as a prisoner. The anti-hero of these movies and novels thus displays the dialectical movement Hegel develops in his preface to The Phenomenology of Mind, where the subject or "mind" encounters its own alien content, implying that it is caught up in what it previously perceived as a separate realm:

Mind, however, becomes object, for it consists in the process of becoming an other to itself, i.e. an object for its own self, and in transcending this otherness. And experience is called this very process by which the element that is immediate, unexperienced, i.e. abstract - whether it be in the form of sense or of a bare thought - externalizes itself, and then comes back to itself from this statement of estrangement, and by so doing is at length set forth in its concrete nature and real truth, and becomes too a possession of consciousness. (96; emphasis added)

For Hegel, the very act of self-affirmation ironically brings into focus the unknown dimension of being, which seems to issue from the outside, but ends up being a part of the subject, even if it previously went unrecognized. While Hegel's dialectical movement seems to imply a totalistic absorption of this "otherness," we must remember that the affirmation of subject or "mind" only sets the stage for the subsequent and inevitable encounter with the alien terrain found within and from without. The supposedly "complete" synthesis creates the conditions for encountering yet another foreign dimension, thus implying that any notion of completion is simultaneously incomplete and haunted by traces of the unknown.

As an example, in noir, the tragic anti-hero encounters other interpretations of their actions that shatter their sense of reality. Maybe, as in the American film The Conversation (1974), they are a surveillant who finds out they are actually being watched by others. Maybe they've notarized a bill of sale of iridium, unknowingly prompting other criminal parties to poison them, not unlike the hero of D.O.A. (1950) who phones in his own death to the police. Maybe they by chance have their phone lines crossed with another, and unwittingly hear the details of a murder plan, only to find out that they are the ones to be knocked off, as happens to be 
the case of Barbara Stanwyck in Sorry, Wrong Number (1948). What we have here are individuals who have led a quiet life but suddenly encounter a traumatically unfamiliar dimension of their existence. They must now face how others view or misinterpret them, how they have become another's object, and are possibly even unknown to themselves. In Hegelian terms, the subject finds him or herself outside, in the object world of foreign substance, not unlike the figure of the double that pervades Padilla's novels, whether it be Espiral de artillería or Amphitryon.2 Such an encounter shatters the reality of these unfortunate souls as they now confront an excess within their subjective frame that has possibly stalked them all along. Prisoners of their own self-deception, of believing themselves to be autonomous individuals and coherent subjects, they must now confront their own unconscious engagement with what lies beyond.

At the basis of this dialectic within noir literature, whether novelistic or cinematic, we can pinpoint an anxiety that signals a subject bewildered by a threatening world laden with unfamiliar corridors and entities. In his seminal essay "The Simple Art of Murder," Raymond Chandler poetically paints the world of Dashiell Hammett's novels, though his description aptly captures noir's more general ethos. He posits "a world in which gangsters can rule nations and almost rule cities, in which hotels and apartment houses and celebrated restaurants are owned by men who made their money out of brothels, in which a screen star can be the fingerman for a mob, and the nice man down the hall is a boss of the numbers racket" (Chandler 99I). This anxiety emanates from noir literature's historical conditions and context, which are marked by instability, crisis, and the unknown. As Sheri Chinen Biesen points out, film noir attests to the political instability of the 405 and $50 \mathrm{~S}$ :

Early noir films created a psychological atmosphere that in many ways marked a response to an increasingly realistic and understandable anxiety - about war, shortages, changing gender roles, and 'a world gone mad' - that was distinctive from the later postwar paranoia about the bomb, the cold war, HUAC, and the blacklist, which was more intrinsic to late I94OS and I95OS noir pictures. (3)

The crises caused by rampant capitalism, the subsequent depression, growing state bureaucracy, as well as the post-war issues of gender, race, and Cold War paranoia, undercut the traditional grounding of nationalist narratives. ${ }^{3}$ According to Borde and Chaumeton, the authors of the first book length study of film noir, A Panorama of American Film Noir 194I-1953 (1955), " $\mathrm{t}]$ he moral ambivalence, the criminality, the complex contradictions in motives and events, all conspire to make the viewer co-experience the anguish and insecurity which are the true emotions of contemporary film noir" (25). 
These novels and films harbor a dimension of uncertainty, whether through a rampant capitalist system or the new social actors that similarly frustrated traditional hegemony.4 GIs returned from the war and found themselves supplanted by women in the work place, at the same time that African American GIs demanded more rights and societal recognition after having fought side by side with their white counterparts. Such a context created a sense of unease, primarily for white men, who saw their control over the home and factory chipped away by these cultural "others." When we add to this the trauma of World War II, we see a traditional idea of nationalism that no longer reflects the hearty masculinity of its imagined origin, but one of impotence that soaks the film noir script or the hard-boiled novel. According to Kelly Oliver and Benigno Trigo, "noir detectives ... continue to navigate the borders of race in ways that manifest an anxiety over lost boundaries and racial ambiguity. Like Uncle John's lectures on proper race relations in Intruder in the Dust, Marlowe's hard-boiled banter about Chinese jade in Murder, My Sweet also circumscribes race relations" (2).

Increased urbanization brought with it more intercultural exchanges, breeding a kind of xenophobia that permeates the written page of, say, a Chandler novel.5 Similarly, movies like Murder My Sweet (1944) or Double Indemnity (1944) cast anti-heroes who are no longer confident in themselves and their masculinity. Their occasionally sadistic desire to control and abuse others, whether it be women or people of color, only reinforces their waning sense of nationality, sex or race. In fact, as Oliver and Trigo have shown, the pathological desire to resuture masculine identity, usually, in film noir, ends up exposing its own weakness (xxxv). By attempting to reinforce identity borders, they only become increasingly fluid and porous. Oliver and Trigo set up their excellent study Noir Anxiety as such:

By interpreting the sites of condensation and displacement of race, sex, and origin, we begin to expose the paradoxical processes through which racial, sexual, and national identities are formed and stabilized at the same time that they are deformed and destabilized. These marginal figures and elements of noir are at the same time defenses against repressed ambiguity in the attempt to stabilize identity and the very return of that repressed ambiguity, which constantly threatens the borders of any stable or proper identity. (xxv)

In film noir, masculine and national identity is dialectical. The effort to reinforce the traditional identity of the white hardboiled male ironically results in masculinity's own unraveling, in its becoming other. These dialectics of noir literature map the unknown, whether it be cultural, 
gender, or sexual difference, often indirectly positing a subject that is wrapped up in the external world in ways he himself ignores.

Consistent with the noir genre, there is a dialectical logic in Padilla's novel and a certain anxiety about this dimension of the unknown. The novel takes place in a fictional Soviet Bloc nation when the end of the USSR is nigh. An otherwise politically neutral doctor, who prides himself on neither getting involved with the oafish authoritarian state nor the petulant student resistance, suddenly finds himself thrown into a web of intrigue, where he must act and deceive others to save himself. While the first-person narrator and protagonist makes use of narrative and lies to reinforce his own safety, innocence, and legitimacy within the state, his actions ironically place him in a world of contingency. The novel's fractured temporal structure oscillates between the narrative present, presumably the early I990s, when the authoritarian structure has already crumbled, and the past, the I950s, when the doctor was brought into the state's inner-workings as an informant. His interpellation into state power, however, is problematic as he never felt any allegiance to the regime but has only fallen inadvertently into the position. As the proverbially impotent noir hero, the nameless doctor is merely pushed along by external forces, and in the moment he decides to act for himself, he dialectically brings himself down.

The novel begins at a point in which the communist state's collapse is imminent. Government officials and their squadron of collaborators, of which the narrator unintentionally forms a part, perfunctorily follow through with their respective duties and the empty gestures of allegiance, while also intuiting their futility. While the state's inner gears seem to be coasting on an inertia that is doomed to run out, a sense of paranoia runs high, especially within circles of authority. Commissioner Magoian, the narrator's immediate superior officer, begins to notice the narrator's lack of loyalty to the regime. The doctor now finds himself in a potentially dangerous situation and must produce some sound information if he is to deflect the commissioner's suspicions and remain in his good graces. He thus concocts a tale about a rebel uprising led by a certain Eliah Bac. Eliah $\mathrm{Bac}$, in fact, is a name familiar to the upper echelons of state power, as it refers to the son of a former navy lieutenant whose submarine sank mysteriously. Then an adolescent, Eliah Bac had insisted that the head of state himself was behind the sinking. The boy later on disappeared, with one of the doctor's patients confiding that he had murdered Bac to silence him, yet the mythology concerning his possible survival and desires for insurrection and vengeance continued to circulate.

By fabricating intelligence about an uprising with Bac at the helm, the narrator/doctor merely attempts to capitalize off of the state's own sense of paranoia and perceived self-deficiencies. However, at some point the state officials realize the story was a lie, and, rather than punish the doctor, they 
surprisingly follow his lead. Magoian and the other higher-ups further develop the fiction, even hiring someone to act as Eliah Bac, since a common enemy always helps to unify the home-front. This fictional ruse, however, takes on larger proportions as the spectral threat published in the local newspapers actually inspires popular uprising. The fictitious insurrection at some point becomes a very real militia opposed to the state, thus giving material reality to what was originally a piece of deceptive fiction. Both the narrator and the state lose control over their own creation. Eventually, the state crumbles, and the unnamed doctor finds himself imprisoned by the new democratic regime. His own deceptive designs, originally intended to reinforce his security, end up enclosing another, supplementary dimension incarnated by the very real insurrectionary masses that leave both he and the state prisoners of their own scheming.

The novel hinges on this frightening encounter with the other zone of subjectivity. The doctor finds himself suddenly entangled and compromised by his presence outside of himself, how he is in the eyes of the other. While this dimension is external, it plays a larger role in constituting his subjectivity than he initially thought. In this sense, the novel rehearses the fluid subjectivity of Padilla's other novel, Amphitryon. According to Siridia Fuertes Trigal, "[a]l enfrentarnos al concepto de identidad nos referimos no sólo a nuestro propio yo, sino también, y sobre todo, al otro. El yo lleva implícito al otro, por eso surge la pregunta: ¿Quién es el otro?” (38).

At the beginning of Espiral de artillería, the doctor attempts to remain on the margin of politics, uninvolved and un-meshed with the fanaticism of the time. In his flashbacks to (ostensibly) the $50 \mathrm{Os}$, the doctor remembers both the violence of the regime in power, as well as the frenzy of the resistance made up of young university students. Among the militants is a beautiful Levantine woman who becomes a romantic obsession for the narrator, who dreams about her from afar. In spite of his amorous fantasies, he attempts to maintain his distance from both the fanatic militancy and the overbearing authoritarian state, as he sympathizes with neither. Supposedly, this distance grants him a certain rationality or objectivity that is lacking in both political poles:

De esta manera envuelto en esos días enmascarados, terminé por acuñar la idea de que el verdadero heroísmo consistía en no involucrarse en esa guerra sin futuro donde todos parecían sentirse obligados a decidir entre romper el orden o defenderlo. Más que el fervor o el desafuero, lo que en verdad forjaría a los héroes de entonces sería su fuerza de voluntad para mantenerse al margen, sus agallas para no atender a los mítines ni aplaudir a quienes los silenciaban, para quedarse en casa y concentrarse en el estudio. (Padilla, Espiral 34) 
The doctor tries to convince himself of his own autonomy, as an agent that is self-sufficient and cut off from external contingency. This, for Vighi, is the sin of ideology demonstrated in film noir: "The lesson of these films is clear: Any 'ideological sin' is founded upon the hubris of a subject who believes himself or herself to be a detached, objective observer" (49). Of course, as Vighi states, the noir film typically counters the ignorance of these individuals by demonstrating their dialectical relation to the world outside: "[The movies] demonstrate that there is no such thing as a subjectivity undialectically detached from the presumed objectivity of the world" (49). While the narrator attempts to reinforce his independence as a rational subject, such efforts often bring about the opposite effect. He finds himself unwittingly thrown into scenarios or roles that challenge his own imagined sense of identity. In spite of his desire to remain separate, in a very Hitchcockian move, the doctor will encounter other readings of his existence that frame him differently, whether as a hero, a villain or an assassin. His attempt to distance himself is never taken seriously by the reader, who sees it as a mere foil for the actual extent of the doctor's embroilment in the outside world.

Curiously enough, the whims of chance (or fate) contradict his desire to remain independent. At one point, while studying at night in the university clinic, a group of student militants allied with the resistance bursts in to the laboratory seeking refuge from the soldiers hot on their trail. In spite of his political neutrality, the doctor is now obliged to give them aid, which obviously weighs on his nerves, even if the beautiful Levantine is among the group. What is more, he finds himself implicated against his will in an activity that he disdains. To complicate things further, he counts himself a suspect, guilty by association with the student radicals. He describes this twist in fate as an exterior force that determines his internal experience:

De pronto mi existencia, habitualmente seca y ordinaria, se veía emboscada por las mismas fuerzas torrenciales que con tanto esmero había intentado sortear. Me parecía una infamia que mi vida pendiese ahora de un hilo tejido por otros, cercenado por otros cuyas ideas jamás me habían quitado el sueño, menos aún la tranquilidad que hasta ese día me había llevado a creer que no hay mejor camino a la inocencia que la más radical pasividad. Pero la suerte, la misma terca suerte que me había llevado hasta ahí, me deparaba sorpresas que todavía hoy no alcanzo a explicarme. (Padilla, Espiral 40)

As he himself states, an outside force is dictating his personal course, be it fate, the state, or some other agency. Like the Hegelian dialectic, where the subject finds itself in alien terrain, the doctor realizes that he is in fact caught up in the outside world, and this disturbs him. 
Vighi identifies this moment when the protagonist goes from subject to object as the traumatic content of noir. When, for example, John Muller in Hollow Triumph (1948), assumes another's identity to escape the ruthless gangsters on his tail, he also inherits the other's gambling debts, effectively exchanging one set of liabilities for another. His efforts to manipulate reality around him, and thus reinforce his status as subject, ironically turn him into an object, a prisoner. As Vighi states, "As if in a short circuit, the subject comes to coincide with the object, the target of his actions" (I). Something similar happens in Padilla's novel. While the protagonist's passivity was supposed to keep him on the margins of politics, this is precisely what brings him into the political arena against his own will. The state interprets his passivity, his indifference toward the insurrection, as sympathy for the regime. Thus, when he is interrogated along with the other militants, he is not sentenced to death, but rather brought into the inner gears of state power as an informant, in spite of his own lack of ideological commitment.

We see here the traumatic realization, not only that the doctor is not in control of his life or destiny, but also that his own subjective existence is anxiously engaged in the world outside. However, the extent and ramifications of such involvement are always veiled from him. Like the Freudian subject who confronts the repressed side of his psyche, so too does the doctor encounter this alternative realm of his own subjectivity, where he functions as the object of others. He must negotiate the hitherto veiled realm of how he appears to those surrounding him, how others interpret or misinterpret him and how his actions and gestures take on additional meanings outside of his own intimate sphere of influence. The doctor has to deal not only with the fact that the state sees him as a trustworthy vessel, but with the townsfolk, who now view him with fear and suspicion, as a dogmatic supporter of the regime. In the townspeople's eyes, since the doctor is the only one who survived the interrogation, he must be an informant. Within his presence, the townsfolk become nervous and paranoid, as he will surely give them over to the police if they happen to make one incriminating move. Of course, this only increases the alienation the doctor suffers, yet it is an alienation caused by his being or existence outside of himself. He is at odds with this alternate dimension of how others read him, now a part of his life, but one that he cannot quite square. As he finds himself in the eyes of the other, as he comes to mean something to the other, anxiety ensues:

Nadie está para entender el drama de quienes en vida se han convertido en símbolos de oprobio o heroísmo ante los ojos de sus semejantes. Los muertos, al menos, llevan en su condición el privilegio de no padecer ya el profundo desarreglo que implica significar algo. Los muertos no padecen cada día la rutinaria arbitrariedad con que 
una conciencia plural, intransigente y sorda colorea de blanco o de negro existencias que de hecho discurrieron como cualquier otra. (Padilla, Espiral 52)

His original efforts at being an isolated, self-contained and coherent entity, have ironically brought him into contact with this repressed dimension of his being, where he finds himself tethered to an unfamiliar world.

The narrator's concoction about Eliah Bac, who had in fact already died secretly some 30 years earlier, initially serves to bolster his own sense of control within this paranoid state. Indeed, narrative and information, whether true or false, connote power within a state so determined by smoke and mirrors, lies, and tacit intimidation. After the state coopts the Eliah Bac lie, staging an entire spectacle of insurrectional violence where they can be the hero that restores order, the doctor is overwhelmed by the bloodshed he has inadvertently caused. This fictitious, though very real movement headed by one who now goes by Eliah Bac, doubtless represents that frightening moment when the doctor finds his own creation now staring back at him in all of its grotesque and uncanny details. We must wonder if the revolt is not symptomatic of this other dimension of himself, that darker, less transparent and often overlooked side, where his actions, ideas and words take on their own monstrous life. In this sense, the doctor passes through the epistemological crisis that Slavoj Žižek associates with the "noir subject," where self-consciousness is always grounded outside of one's self: "If, as the Hegelian commonplace goes, self-consciousness is selfconsciousness only through the mediation of another self-consciousness, then my self-awareness ... causes the emergence of a decentred 'it thinks'" (209). In this sense, does not the doctor very much find himself externalized in the palpable havoc of the multitude, of which he is the unconscious originator? This point reminds us of what Marcie Paul has observed about Padilla's engagement with metaphysical detective fiction, wherein the detectives "discover that the threat lies within themselves instead of emanating from a menacing other" (199).

The multitude, with all of its rambunctious, uncontrollable energy, can be seen as a materialization of the doctor's id. He subsequently becomes the object or prisoner of this horrific other dimension that has possibly been playing the upper hand all along. Such an inversion is reinforced at the end of the novel, when the state casts the doctor as Eliah Bac's assassin, as a would-be hero of the nation, even if the doctor has not killed anyone. His own creation, Bac, is that which condemns him, something which becomes clearer later on when the authoritarian regime is brought down and democracy restored. At that point, the doctor is seen as a criminal, since Bac's very real sympathizers, who knew nothing of the political lies and conspiracies, are now running the country. 
At this point, the doctor and the state coincide. Just as the doctor encounters the unforeseeable ramifications of his own actions, so too does the state become a prisoner to its own designs. While the state officials had originally supported the Bac lie as a means of regaining legitimacy, the movement eventually catalyzes enough discontent among the multitude to become a very real insurrection. At that point, we must wonder if the man going by the name of Eliah Bac is actually acting any more, or hasn't truly signed on with the insurrectionist militia. At any rate, the state loses control over the movement, and finds its own repressed mirror image in the multitude. Like the doctor, the regime officials find themselves in this other that is staring back at them, to whom they are now subservient.

However, throughout the novel, the state has always seemed to harbor this chaotic flip-side to its supposedly rational and hyper-controlled order. None of the government officials have a complete grasp of what is going on at any moment, of who knows what and who is deceiving whom within this morass of bureaucratic circuits. The doctor, for example, is never sure why the state has hatched this myth of him as the heroic assassin who finally eliminated Bac. While the state attempts to leverage the farcical rebellion to its advantage, it only sows the seeds of its own destruction. During the doctor's period of convalescence, the popular multitude overthrows the authoritarian regime and restores democracy. Like the fallen heroes of film noir, the fictional nation endeavors to reinforce its power and centrality only to become subservient to its grotesque other: popular democracy.

The amorphous multitude that we find in the novel prompts an interesting point of contact between the political anxieties that we find in classic North American noir and Ignacio Padilla's novel and context. Like the unpredictable masses that undermine Malombrosa, so too does the classic noir genre owe its anxiety to a kind of political agent from outside women, people of color, etc. - which show themselves to have been a part of the body politic at all times, challenging hegemony. Padilla's novel undoubtedly maps the uncertainty of Mexico's own transition into the global world. Like Mexico at the end of the past century, the fictitious satellite nation finds itself infiltrated on all fronts by the unpredictable forces from outside, among them, the global capitalist market that sings the death knell of Soviet protectionist politics. In the novel, the politics of isolationism and national autonomy have turned into a pantomime that state employees superficially repeat without any sincere investment.

The novel leaves us with the afterimage of Mexico's own inability to remain isolated from the globalized world. Ultimately, the nation finds itself fully enmeshed in the unpredictable and phantasmatic market flows from what appeared to be 'the outside,' but have now fully asserted themselves within. Anne Marie Stachura signals the importance of this critique of neoliberalism in Amphitryon. According to Stachura, Padilla's work 
foregrounds the challenges of the individual state to navigate the neoliberal landscape referring to specifically "the myth of the fair and equitable functioning of autonomous Nation-States in the age of globalization" (285). Ignacio Sánchez Prado likewise identifies a critique of neoliberalism in the larger scope of the Crack movement, which he couples with an interrogation of Mexican nationalist rhetoric: "En sus orígenes, el crack concibió una estética que criticaba de manera simultánea a la modernidad nacionalista que ata a la literatura a un proyecto institucional de país, y a la modernidad neoliberal que considera a la cultura una función exclusiva del mercado" ("Utopía” II).

The diverse conspiracies that float throughout Espiral de artillería easily invoke the unforeseeable, secretive whims and fancies of private capital that undermine Mexican national stability. Eliah Bac's insurrection is connected, at times, to the CIA, which historically has affirmed a neoliberal agenda. Yet we cannot limit this reading to anxiety about elusive market forces. Indeed, the novel's mood of conspiracy invokes just as well the revolutionary multitudes that oppose international capital. Indeed, the fear that Eliah Bac's movement provokes conceivably assumes any form of the unknown, or the other, which potentially poses a threat to supposed national stability. In an interview with Tomás Regalado López, Padilla himself asserted that Eliah Bac stands in for the EZLN:

Me di cuenta de cuánto tenía que ver con lo que yo estaba viviendo en ese momento en México, que era la falsedad de la democracia; la novela se convierte en un cuestionamiento brutal sobre la transición democrática, que era lo que estaban viviendo los rusos pero que también se estaba viviendo en México a principios de siglo. Al mismo tiempo que yo pensaba que era una novela sobre los defectos de la democracia en la Rusia de hoy, descubrí que era una novela sobre los defectos de la democracia en el México de transición, con su guerrillero de utilería, que era el Subcomandante Marcos. (Regalado, Historia personal I62-63)

In this regard, the novel seems to offer a critique of neoliberalism, consistent with other noir writers from Mexico, such as Paco Ignacio Taibo II. William Nichols finds within both Taibo and Spaniard Vázquez Montalbán a deep suspicion and critique of modernity and neoliberalism. He reads their work as "a postmodern combination of texts that exhibit the ludic nature of detective fiction while they simultaneously convey deeply political messages that subvert hegemonic narratives of modernity by investigating issues of truth, power, dominance, and justice in Mexico and Spain during the age of neoliberalism" (Nichols I8). Persephone Braham makes a similar observation about Hispanic detective fiction: "The detective novel came late to Hispanic letters, and one of its defining characteristics has been a concern with foreign paradigms of modernity, and ultimately the failure of liberalism 
and its constituent elements in a Hispanic context" (ix). Like Taibo, Padilla seems to exhibit a certain unease about modernity in general and the problems of democracy in Mexico.

However, while Padilla's novel represents these connections to the outside as cause for anxiety, not unlike what we see in classic film noir, it also seems to affirm the Crack's own literary ideology as cosmopolitan, world literature. This dialectical engagement with the world reflects a sense of disquiet on one level, while it also coincides with the desire of writers like Padilla and Volpi to affirm a kind of globality. In the 1996 "Manifiesto del Crack," Padilla envisions a kind of Bakhtinian "cronotopo-cero" for his work that eludes concrete notions of space and time, and embraces a more global territory: "Lo que buscan las novelas del Crack es lograr historias cuyo cronotopo, en términos bajtinianos, sea cero: el no lugar y el no tiempo, todos los tiempos y lugares y ninguno" (219). Tomás Regalado López describes the Crack's literary tendencies as "una actitud cosmopolita que deniega tradicionales asociaciones entre novela latinoamericana $\mathrm{y}$ problemáticas regionales, temáticas nacionalistas o color local" (Historia Personal 26). Ignacio Sánchez Prado similarly describes Padilla's novels as "excellent examples of how he engaged with world literature to produce fiction that sought worldly status." (Strategic Occidentalism I24).

Thus, the Crack's literary project, as conceived by Padilla, entails a being-in-the-world that transcends national borders and reveals an artistic practice that places the writer outside of his immediate context, allowing him to locate himself elsewhere. In the same manifesto, Padilla describes the spatial and temporal chaos of globalization, as a space where the Crack writers find themselves ensnared: "La dislocación en estas novelas del Crack no será a fin de cuentas sino remedo de una realidad alocada y dislocada, producto de un mundo cuya massmediatización lo lleva a un fin de siglo trunco en tiempos y lugares, roto por exceso de ligamentos" (219). Read in this manner, the doctor's downward spiral into an external world of contingency and fate, emblematizes the Crack's own literary ideology, which, through, literature, allows a writer like Padilla to position himself in the world. The dialectics of noir narrative posit an anti-hero who finds himself uncomfortably embroiled in a threatening world from outside. In dialectical fashion, he realizes his own subservience to unknown and menacing forces. However, such a Hegelian attachment to the world, when read within the context of the Crack's aspirations, takes on a less tragic hue as it reinforces a significant part of their literary project. Padilla's image of the "cronotopo-cero" implies a writer that is dialectically caught up in a space beyond national borders.

Obviously, Padilla has been critical of the alienating and destabilizing effects of neoliberalism, ${ }^{6}$ yet there is also a clear desire to engage with a global tradition of literature, and with cultural difference. It is no 
coincidence that the majority of Padilla's novels are set in various locations far from Mexico, let alone Latin America. Amphitryon, as is well known, is a political thriller that takes place in Austria, Germany, Switzerland, and the U.K., all the while reflecting on issues of false legacy and stolen identities. $L a$ gruta del toscano (2009) takes as its setting Dante's Inferno as discovered in the Himalayas. El daño no es de ayer (20II) presents a suspense story of spiritism set in an apparently American Midwest town after World War II, all the while making sufficient allusions to Borges for good measure. Si volviesen sus majestades (1996) could take place in Mexico, but it also seems to take place in medieval Spain, even if the castles are dotted with refrigerators and telephones. According to Ramón Alvarado Ruiz, "El espacio pierde su concreción al momento de adquirir nuevas significaciones, ya no podemos asir la imagen que de él nos hacemos una vez que es llevado a otro nivel metatextual" (I86). Without a doubt, Padilla's work affirms the right of the Mexican writer to a world tradition and to philosophically find himself beyond. In her excellent study of La gruta del toscano, Rosario Hubert highlights the Borgesian ideal of a "universal geography available to the peripheral writer, for he transcends the global scope of the world as his patrimony and takes on literary settings" (50). As Ignacio Sánchez Prado points out, Crack writers like Padilla and Volpi negotiate the neoliberal publishing industry and exoticizing politics of "world literature," while also instantiating a desire to transcend borders:

Books like En busca de Klingsor are more the result of negotiating the Latin American writer's increasingly difficult situation in the context of neoliberal transnational publishing practices than of capitulating to it. The appeal to popular genres and the world literary form, the writing of what Rebecca Walkowitz recently called "borntranslated" fiction, and the harnessing of topics such as Nazism, are all associated with the Latin American writer's ability to reach audiences and readers beyond the narrow confines of national and local literary worlds. (Strategic Occidentalism II2)

Consistent with Sánchez Prado's observation about "popular genres," the noir tradition that informs Espiral de artillería, as well as many of Padilla's other works, plays a key part in this cosmopolitan-driven literature. Film and roman noir, as endlessly rewritten literary codes already have a place within postmodern aesthetics.7 What is more, film noir's origins are themselves notably international, as the term "film noir" only gained semantic exchange value when theorized by the French in the 40s and $50 \mathrm{Os}$, culminating in Borde and Chaumeton's A Panorama of American Film Noir: 194I-1953. Many of the early French theorists of film noir found in these American movies a continuation of their own poetic realism as seen in films by Renoir (Fay and Neiland I6-19). Additionally, significant entries in the film noir canon were directed by Jewish, European expatriate directors who 
had fled the anti-Semitism of their homeland, such as Fritz Lang, Billy Wilder, and Otto Preminger, and who had also been key figures within the expressionist scene of 20 a and 30 S Weimar cinema. Interestingly enough, Padilla makes an allusion to expressionist cinema, an aesthetic predecessor to film noir, in one of the final moments of Amphitryon when Daniel Sanderson has been kidnapped in London by "Humphrey Bogart" and an enigmatic driver, whom he suspects to be Adolf Eichmann. Sanderson describes the foggy London streets at night as "una mala película expresionista" (262), thus reinforcing the cinematic imagery already conjured up by the name "Bogart."

In addition to invoking the stature of the international aesthetic tradition of film noir, by rehearsing the genre's dialectical tension in Espiral de artillería, Padilla traces the aesthetic coordinates of a sort of entanglement with the world. Héctor Hoyos similarly finds behind Padilla's use of cinematic icons an engagement with a global space:

The path to a global historical consciousness may pass through images of Bogart and Rains walking into the fog, but it does not stay there. The creative tension between historical referents, pop-culture images, and local concerns demands going beyond the reductionist thinking about globalization as interconnectedness. Connections are as much about form as they are about content: globalization involves actual people with historical baggage who filter the experience from other coordinates of the world through the ones they are most directly involved in. (45)

While this presence of the global signals a sense of anxiety about the unknown, it also takes on a utopian hue as it implies an artistically fruitful involvement with the world. We see here an ideological shift from classic noir where the uncertainty about otherness and the unknown becomes, now within the Crack's postmodern and cosmopolitan project, an opportunity to lose oneself within a global artistic context. Without a doubt, Padilla has voiced his own critique of neoliberal, globalizing logic. However, he also seems to hold out hope for literature and creative practice as a utopian flow beyond the strictures of national borders which, ironically, takes global capitalism as its condition of possibility. As noir is rewritten by Padilla, its instability ceases to have the nihilistic punch it once had, as this very critical unease becomes an opening onto the world.

Brigham Young University 


\section{NOTES}

I The name of Volpi's protagonist, Francis Bacon, is a clear homage to the sixteenth-century English philosopher and scientist, also named Francis Bacon who is often credited for developing the scientific method. In En busca de Klingsor, Volpi's character reflects at length on the legacy and weight of such a name as he, like his namesake, also happens to be a physicist. The irony of such a name, however, becomes clearer as Volpi's Bacon is ultimately unable to arrive at an entirely rational solution at the end of the novel, but encounters, instead, the uncertainty of reality, knowledge, and the physical world.

2 Claudia Macías Rodríguez offers an enlightening reading of this motif of the double, coupled with memory, in Padilla's better known Amphitryon, where she makes many observations that could easily apply to Espiral de artillería. She sees the notion of the double as something which complicates ideas of identity and origin: "En este juego de referencias dobles, el relato deja entrever el problema mayor que asume, el de la identidad y del origen (y lo original, por extensión)" (Macías Rodríguez 28). This proliferation of doublings contributes another fruitful dimension of the dialectic, namely that moment when the subject finds himself externalized, thus encountering that foreign part of himself within the world of substance.

3 According to Andrew Pepper, novels by Dashiell Hammett and Horace McCoy, evince a certain anxiety concerning dehumanization at the hands of a rampant capitalist system. However, rather than reinforce a kind of revolutionary optimism, according to Pepper, novels like Red Harvest (1929) and They Shoot Horses, Don't They? (1934) lay bare an exploitative system without prescribing any way out: "McCoy is making an important point: life is constant struggle and art needs to reflect some of this unpleasantness. Like Horkheimer and Adorno, he offers us what amounts to a Marxist critique of capitalist society but with no unrealistic revolutionary hopes. As with Red Harvest, McCoy's is a critique which, in the end, yields nothing and goes nowhere: capitalism is not about to implode under the weight of its contradictions. What Horses demonstrates, and what Horkheimer and Adorno fail to see, is the subversive possibilities inherent in a popular form that is somehow able to reflect upon, or compel its readers to reflect upon, its own grimly exploitative vision" (Pepper).

4 Jennifer Fay and Justus Nieland likewise signal the uprooting effects of modernity and capitalism in a novel like The Postman Always Rings Twice by James Cain. According to them, increasingly fluid forms of capital and enterprise within the early twentieth century create a sense of cultural nomadism that one finds stigmatized in the profligate drifters and delinquent social climbers like Frank and Cora in Cain's novel, themselves nomads that knock off Cora's "greasy" immigrant husband, Nick, in order to take over his small business. Of course, as is to be expected in this roman noir, they tie their 
own noose through their avarice and scheming. Beyond stigmatizing them for their profligacy, however, the novel seems to evince a certain anxiety about the unpredictability of capitalism itself. Rather than reinforce the rootsy, homegrown individualism of American nationalism, capitalism begets uncouth drifters and schemers, who ironically, become the victims of their own scheming and leave the American dream decidedly uprooted: "The plot makes clear that Postman is a story about rootless people and, more importantly, a restless modern existence pervaded by chance and desire, risk and accident" (4). While capitalism seems to safeguard individualism, it simultaneously presupposes the placement of this individual within a network of exchanges, desires and power relations that are difficult to map, and that likewise bring about a kind of subjugation.

5 While plenty of hard-boiled novels exude uncertainty concerning the many caprices of market capitalism and growing corporate power, there is also a notable anxiety about increased government bureaucracy and cultural difference. According to Sean McCann: "Alongside the sudden prominence of organized crime, which transfixed popular attention in the twenties, the recent growth of corporate enterprise and of the federal government each appeared to portend fundamental transformations in American society during the twenties. So, too, did the expansion of the nation's cities, the personal liberties and cultural and ethnic diversity of which had become the central grievance in a wave of xenophobic suspicion that coursed through every corner of public life in the years after the war. The hard-boiled crime story took those concerns about bureaucracy and about cultural disorder and made them into the materials of a resonant popular myth."

6 In his essay "El crack a través del espejo" Padilla contextualizes the melancholia and skepticism of his generation, which differs markedly from the militancy of the previous generation. That said, his own skepticism should not be confused with neoliberal apologetics. As he himself states in his essay: "Si bien es cierto que la resaca del triunfo del neoliberalismo no es menos agobiante que la melancolía heredada de nuestros mayores, igualmente es verdad que el desarrollo de nuestra consciencia en el mundo nos empujó de pronto a reconocer que nadie, sobre todo un artista en ciernes, puede estacionarse en la inacción o el escepticismo y aun así pretender seguir existiendo, no digamos creando" (Padilla, "El crack" 32).

7 In Postmodernism or the Cultural Logic of Late Capitalism, Fredric Jameson references the nostalgia of postmodernism as "never a matter of some oldfashioned 'representation' of historical content, but instead [something that] approached 'the past' through stylistic connotation, conveying 'pastness' by the glossy qualities of the image" (I9). Subsequently, he alludes to Lawrence Kasdan's neo-noir film Body Heat, a remake of Double Indemnity: "The word remake is, however, anachronistic to the degree to which our awareness of the preexistence of other versions (previous films of the novel as well as the novel 
itself) is now a constitutive and essential part of the film's structure: we are now, in other words in 'intertextuality"' (Jameson 20).

\section{WORKS CITED}

A lvarado Ruiz, Ramón. Literatura del Crack: Un manifiesto y cinco novelas. Guadalajara: Arlequín, 2016.

borde, raymond, and étienne chaumeton. A Panorama of American Film Noir: 194I-I953. Trans. Paul Hammond. San Francisco: City Lights Books, 2002.

—. "Towards a Definition of Film Noir." Film Noir Reader. Eds. Alain Silver and James Ursini. New York: Limelight Editions, 1996. 17-25.

braham, Perse Ph one. Crimes against the State, Crimes against Persons: Detective Fiction in Cuba and Mexico. Minneapolis: $\mathrm{U}$ of Minnesota P, 2004. CHIn En BIESEn, ShE RI. "The Simple Art of Murder." Later Novels and Other Writings. New York: The Library of America, 1995. 977-92.

-. Blackout: World War II and the Origins of Film Noir. Baltimore: The Johns Hopkins UP, 2005.

fay, Jennifer, and Just us neiland. Film Noir: Hard-Boiled Modernity and the Cultures of Globalization. New York: Routledge, 2010.

fuertes trigal, siridia. "Los mitos clásicos en la obra de Ignacio Padilla: reescrituras modernas y versiones subversivas." Revista de Literatura Mexicana Contemporánea 17 (2010): 31-4I.

H E G EL, G. W. F. The Phenomenology of Mind. Trans. J.B. Baillie. London: George Allen \& Unwin, I93I.

Hollow Triumph. Dir. Steve Sekely. United States. Brian Foy Productions. 1948. н о о оs, не́ст о R. Beyond Bolaño: The Global Latin American Novel. New York: Columbia UP, 2015 .

hubert, Rosario. "Rewriting Travel Literature: A Cosmopolitan Critique of Exoticism in Contemporary Latin American Fiction." Peripheral Transmodernities: South to South Intercultural Dialogues between the LusoHispanic World and "the Orient." Ed. Ignacio López Calvo. Newcastle: Cambridge Scholars Publishing, 20I2. 42-6r.

Jameson, fRedric. Postmodernism or the Cultural Logic of Late Capitalism. Durham: Duke UP, r991.

MACíAS RODRíGUEZ, CLAUDia. "Memoria y olvido en torno al problema de la identidad en Amphitryon de Ignacio Padilla." Revista de Literatura Mexicana Contemporánea I5 (2009): 27-37.

marista in, mónica."Ignacio Padilla, un cuentista de pura cepa que amó al Quijote y a sus amigos." Sin Embargo. 2I August 2016. Web. 3 July 2017.

m CCA n n, SEA "The Hard-Boiled Novel." The Cambridge Companion to American Crime Fiction Cambridge. Ed. Catherine Ross Nickerson. Cambridge: Cambridge UP, 201 I. Proquest. Web. 8 Nov. 2018. 
Nich ols, william. Transatlantic Mysteries: Crime, Culture and Capital in the "Noir Novels" of Paco Ignacio Taibo II and Manuel Vázquez Montalbán. Lewisburg: Bucknell UP, 201 .

oliver, Kelly, and Benigno trigo. Noir Anxiety. Minneapolis: U of Minnesota P, 2003 .

Padilla, ignacio. Amphitryon. México: Punto de Lectura, 2000.

—. "El Crack a través del espejo." Si hace crack es boom. Barcelona: Umbriel Editores, 2007. 27-40.

—. Espiral de artillería. Madrid: Espasa, 2003.

-. et al. "Manifiesto del Crack." Crack. Instrucciones de uso. Ed. Ricardo Chávez Castañeda, et al. México: Mondadori, 2004. 209-26.

PAUL, MARCIE. "The Search for Identity: The Return to Analytic Detective Fiction in Mexico." Hispanic and Luso-Brazilian Detective Fiction: Essays on the Género Negro Tradition. Eds. Renée W. Craig-Odders, Jacky Collins, and Glen S. Close. Jefferson: McFarland, 2006. I80-203.

Pe P P R, An D RE W. "The American Roman Noir." Nickerson. The Cambridge Companion to American Crime Fiction Cambridge. Ed. Catherine Ross Nickerson. Cambridge: Cambridge UP, 2010.

REgALAdo López, to más. "De Borges a Volpi: 'En busca de Klingsor' y el relato policiaco metafísico." Realidad y ficción criminal. Dimensiones narrativas del género negro. Eds. Alex Martín Escribá y Javier Sánchez Zapatero. Valladolid: Difácil, 2010. 135-67.

—. Historia personal del Crack: Entrevistas críticas. Valencia: Albatros, 2018. SÁNCHE Z PRADO, IGNACI o. "La utopía apocalíptica del México neoliberal." AlterTexto 5 (2007): 9-15.

-. Strategic Occidentalism: On Mexican Fiction, the Neoliberal Book Market and the Question of World Literature. Evanston: Northwestern UP, 2018.

Sorry, Wrong Number. Dir. Anatole Litvak. United States. Paramount. 1948. STACHURA, ANnE maRiE. "Transnational Injustice: The Subversion of Myth in Ignacio Padilla." Myth and Subversion in the Contemporary Novel. Eds. José Manuel Losada Goya and Marta Guirao Ochoa. Newcastle upon Tyne:

Cambridge Scholars Publishing, 20II. 277-86.

The Conversation. Dir. Francis Ford Coppola. United States. Paramount. 1974. D.O.A. Dir. Rudolph Maté. United States. United Artists. I949.

V I G H , FA B I . Critical Theory and Film: Rethinking Ideology through Film Noir. New York: Continuum, 2012.

Vo L P I, Jo R GE. En busca de Klingsor. Barcelona: Seix Barral, I999.

—. La paz de los sepulcros. México: Editorial Aldus, 1995.

ŽIŽE K, SLA VoJ." "The Thing That Thinks: Kantian Background of the Noir Subject." Shades of Noir. Ed. Joan Copjec. New York: Verso, I993. 199-226. 